\title{
IMPLICATIONS OF CONSTITUTIONAL CHANGE FOR THE OIL AND GAS INDUSTRY
}

\author{
ANDREW R. THOMPSON*
}

\begin{abstract}
This article relates the problems of constitutional change directly to the oil and gas industry. The article outlines the present constitutional position of the oil and gas industry under the B.N.A. Act, 1867, comments on the current psychological and philosophical approaches to constitutional change, identifies the specific points of clash between the federal and provincial governments with respect to regulation of the oil and gas industry, and concludes by postulating some guidelines for constitutional change affecting the oil and gas industry.
\end{abstract}

When the Second Annual Oil and Gas Law Seminar was held at Banff in 1963, constitutional change in Canada was a remote consideration-too remote to merit even a sideways glance by those who presented papers on "Constitutional Law Problems in Canadian Oil and Gas Legislation." 1 Now, a panelist at the Alberta meeting of the Canadian Bar Association in Jasper, tells us that a total revision of the constitution in Canada is no longer a question of "if" but merely a question of "when," and that the first steps towards change have been taken." It is time, therefore, to take a second look at the implications of constitutional law for the oil and gas industry.

One says "for the oil and gas industry"-not merely "for oil and gas conservation legislation." Everyone is aware that conservation legislation and administration in Canada, as exemplified by the conservation statutes and boards in the western provinces, are providing not merely a technical regulation of the industry, but a total framework, alongside federal agencies such as the National Energy Board, for the economic organization and operation of the industry in Canada. Therefore, when one speaks of the implications of constitutional law with respect to conservation legislation, he is really speaking of implications affecting the oil and gas industry in its total aspects.

The approach to the subject will be

(1) to review briefly the present position under the B.N.A. Act, 1867;

(2) to comment on the psychological and philosophical approaches to the constitution that are evident in current writings about constitutional change;

(3) to identify the points of clash between federal and provincial interests with respect to the oil and gas industry; and

(4) to postulate some principles or guidelines that should be in the minds of those with particular responsibilities for the industry during the process of change which the next few years shall bring.

(1) The Present Position under the B.N.A. Act, 1867

It is time to remind ourselves that, in the opinion of many writers about constitutional law, not only the provincial legislation governing

* LL.B. (Man.), LL.M. (Toronto), J.S.D. (Columbia). Member of the Law Societies of Alberta and Manitoba. Co-author, Lewis and Thompson, Canadian Law of Oil

1 These papers are published in the Petroleum Law Supplement, (1964) 3 Alta. L. Rev.

2 Professor Ivan Head, presently associate Counsel for the Constitution, Department of Justice, Ottawa. 
the pipelining and marketing of natural gas, but also provincial legislation providing for the prorationing of oil to market demand, is ultra vires as an invasion of federal legislative competence under the B.N.A. Act, 1867. Alternatively, in both cases the legislation may be supplanted by federal legislation under the paramountcy principles of the B.N.A. Act, 1867. For example, Mr. Holland, in his article entitled The Federal Case $^{3}$ contended that the federal parliament could control the pipelining and marketing of natural gas in Alberta under its powers over interprovincial works and undertakings, ${ }^{+}$and over trade and commerce, ${ }^{5}$ and that the provincial restrictions on the export of natural gas under the Alberta Gas Resources Preservation Act, $1956,{ }^{\circ}$ are ultra vires as a violation of $\mathrm{s}$. 121 of the B.N.A. Act, 1867, which requires free trade between the provinces. He concluded that:

It is not contended that the cases lead irresistably to the conclusion that the Parliament of Canada has legislative jurisdiction over pipelines such as Britamoil and A.G.T.L. But, such conclusion is a small step for a federally-oriented court to take, and it is submitted that the Supreme Court of Canada has exhibited such an orientation in the Farm Products Case...?

It might be commented that federal orientation of the Supreme Court of Canada was further exhibited in the recent decision in the Offshore Minerals Reference. ${ }^{8}$

So far as prorationing of oil is concerned, John Ballem, in his article entitled Constitutional Validity of Provincial Oil and Gas Legislation," dismissed both our honoured guests from their posts as chairmen of provincial conservation boards by asserting that the provincial conservation legislation is ultra vires because it creates what is essentially a products-marketing scheme reaching beyond provincial boundaries. John Rathwell speaks in favour of constitutionality in his article entitled Constitutionality of the Prorationing Scheme in Alberta. ${ }^{10} \mathrm{He}$ contends that the prorationing scheme is a valid expression of provincial purposes, being in pith and substance a scheme for the prevention of physical and economic waste and not merely a marketing scheme. But such support is of uncertain comfort to the provincialist who is aware that when an appeal is made to the pith and substance doctrine to found provincial jurisdiction, there is implicity a federal aspect to the matter, and any federal legislation that is enacted in the field will usurp provincial jurisdiction to the extent that there is conflict.

This brief review of the present position under the B.N.A. Act, 1867, can be concluded by the safe statement that the current legislative framework for the economic regulation of the oil and gas industry rests on tenuous and insecure foundations, and that the federal parliament can pre-empt most of the legislative powers.

3 (1964) 3 Alta. L. Rev. 393.

\& British North America Act, 1867 30-31, Vict. c. 3, s. 92 (10) (a).

s Id., S. $91(2)$

c S.A. 1956, c. 19.

7 (1964) 3 Alta. L. Rev. 393, at 402.

8 Reference re Ownership of Off-Shore Mineral Rights, [1967] S.C.R. 792; (1968) 65 D.L.R. (2d) 353 .

o (1963) 41 Can. Bar Rev. 199.

10 (1965), 4 Alta. L. Rev. 142. 
(2) The Psychological and Philosophical Approaches to Constitutional Change

In this current atmosphere of constitutional change, writers on the constitution in Canada are obviously directing their attention to the constitution that ought to be rather than to the constitution that is. Not so obviously, even when they refer to the constitution that is as a datum line from which change can be projected, it is not what the constitution says, or even what the constitution has been interpreted to say, that engages their attention, but rather what the constitution does. They are asking not about the distribution of legislative powers under s. 91 and s. 92 of the B.N.A. Act, 1867, but about the distribution of authority and influence between Ottawa and the Provinces as it is in fact manifested, and they are inquiring more into how the institutions of Confederation work than into how the provisions of the B.N.A. Act, 1867, establish Parliament and the courts. The paradox is complete. Whereas in 1963, the writers of the seminar papers at Banff talked about the sections of the B.N.A. Act, 1867, and the interpreting case law, and did not mention constitutional change, the writers of today talk about constitutional change and do not mention either ss. 91 and 92 or the case law.

In changing their emphasis from analytical studies of the constitutional cases to policy-oriented studies of the institutions and workings of Canadian federalism, lawyers are at last undertaking the tasks that social scientists have for some time advocated as the only real and significant ones for our times. It has been said by Frank Scott, the well-known McGill constitutional law professor, that:

The social scientists of every type are in the saddle, and if the cold voice of the constitutional lawyer is heard at all, it carries little weight. The firm statement that "This is the law" is apt to be met by the rather irreverent comment, "So what!"11

Rather, the social scientists have enshrined the concept of "co-operative federalism" as their imperative, and they little conceal their belief that for them it means "co-operation to evade the constitution and the lawyers!" Bora Laskin describes the same phenomenon when he writes:

Moreover, from the late thirties on, the political disposition appeared to be to rely on constitutional amendment for effective change; and, failing that, to seek to reconcile the difficulties of divided jurisdiction through administrative cooperation which would permit unified action while leaving existing judiciallydeclared limits of constitutional authority undisturbed. Clearly enough, political federalism has been, for many years, much more dominant than legal federalism in this country.12

Even the most liberal-minded legalist must be affected by the urge to probe deeper than the provisions of the B.N.A. Act, 1867, and the cases, if his eyes are not shut to the society around him. Surely all oil and gas lawyers have asked themselves why it is that a system so profoundly affecting Canadians as the economic organization and operation of the petroleum industry can sail smoothly on the constitutional seas when constitutional lawyers say that it should have foundered long ago on the shoals of constitutional invalidity. Any affected person can challenge a provincial statute as ultra vires. Our neighbours in the

11 Canadian Federalism: The Legal Perspective, (1967) 5 Alta. L. Rev. 263, at 264.

12 Reflections on tre Canadian Constitution After the First Century, (1967) 45 Can. Bar Rev. 39, at 396. 
United States are constantly before the courts to have the constitutional waters charted for them. One may explain the lack of constitutional challenge in Canada by saying that a constitutional case is too expensive to be undertaken by the ordinary litigant, or that it is not expedient for the plaintiff of substance and influence to challenge the legislation of the government with which he must deal on a day-to-day basis. Or maybe the answer is that Canadians are not litigous, or that the constitution and the cases provide too uncertain a measure for reasonable prediction of success or failure, and that they are too loose-textured to prevent the fruits of victory in court from being snatched away by a re-clothing of the offending statute in more respectable constitutional garb. For whatever reasons, the fact is that Canadians are not now applying the Canadian constitution to their affairs in other than a spasmodic and intermittent fashion.

Therefore, the psychological and philsophical approach to constitutional change in Canada today is to ask "what" and "why" with respect to the social reality behind the constitution and its cases. This approach leads the writers in the special centennial issue of the Canadian Bar Review of 1967 to comment on such topics as the future role of the federal courts, ${ }^{13}$ on the forms and limitations of co-operative federalism, ${ }^{14}$ and on the philosophical bases of Confederation itself. ${ }^{15}$ Professor Head says that the approach of the present government in Ottawa will be to concentrate on these broad issues at the beginning. Only after the civil rights issue is settled and the institutions of the new federalism are designed will the dialogue turn to the provisions for the division of legislative competence between Ottawa and the provinces and to the entrenchment of these provisions.

The conclusion, therefore, is that the oil and gas lawyer will find little in the contemporary legal literature to assist him in assessing the implications of constitutional change for the petroleum industry. In fact, he might even be led to conclude that the traditional role of law and of the lawyer will have little signficance under a future constitution. One writer in the Canadian Bar Review offers instead a "policyscience model" for a "fresh approach to constitutional law."18 But, lest one despair that the lawyer's role in constitutional matters is being preempted by social scientists in this twentieth century, he should be reassured that eminent constitutional lawyers do not see the future in this grim light. Dean Lederman of Queen's University law school, writes that:

Co-operation and mutual good will we certainly need, but no amount of them will do away with the absolute necessity for a primary authoritative distribution of powers and resources in our federal constitutional document.17

Frank Scott, of McGill Law School, makes the point that:

The law which is about to change gives us a present location, a latitude and

13 Edward McWhinney, Federal Supreme Courts and Constitutional Review, (1967) 45 Can. Bar Rev. 578; Jacques Yvon Morin, LeQuebec et L'Arbitrage Constitutionnel: De Charybde en Scylla, (1967) 45 Can. Bar Rev. 608.

14 W. R. Lederman. Some Forms and Limitations of Co-operative Federalism, (1967) 45 Can. Bar Rev. 409.

15Claudius O. Johnson, Did Judah P. Benjamin Plant the "States Rights" Doctrine in the Interpretation of the British North America Act? (1967) 45 Can. Bar Rev. 454.

16 J. Noel Lyon. A Fresh Approach to Constitutional Law: Use of a Policy-Science Model, (1967) 45 Can. Bar Rev. 554.

17 (1967) 45 Can. Bar Rev. 409. 
a longitude, and thus our bearings. . . . The existence of a functioning constitutional law prevents us wandering around in circles. ${ }^{18}$

One can confidently predict that a new Canadian constitution will have a statement on the distribution of legislative powers and that this statement will be given legal authority. Indeed, the very drive for a new constitution implies a strong public need in Canada not only for a clear and definite statement on the distribution of legislative powers, but also for an institution with a clear mandate to enforce this distribution of powers. Therefore, there will be a constitutional law and there will be a constitutional court, by whatever names they may be called. Therefore, it is of the greatest significance to enquire what the legal implications of the new constitution will be for the petroleum industry.

\section{(3) The Points of Clash Between Federal and Provincial Interests}

With Respect to the Petroleum Industry.

To follow the admonitions of the social scientist by examining the social reality behind the present constitution and the cases, it is proposed to identify, so far as possible, the points of clash between federal and provincial interests in the oil industry. At the outset, these points of clash will be identified as (a) ownership of the resource; (b) revenues from the resource; (c) control of the business of exploiting the resource and (d) control of the uses to which the resource may be put.

(a) Ownership of the resource.

Section 109 of the B.N.A. Act, 1867 gave to each of the constituting provinces the ownership of natural resources within its boundaries. In the case of the provinces which later joined confederation, the position varies. British Columbia and Prince Edward Island gained their natural resources on entry into Confederation. The prairie provinces did not. It was not until 1930 that the transfer agreements passed ownership and control from the federal government to the governments of Alberta, Saskatchewan and Manitoba. Newfoundland retained its resources. The resources in the Yukon and Northwest Territories are owned by the federal government. The Offshore Minerals Reference ${ }^{19}$ gave the federal government rather than British Columbia the ownership of the mineral resources of the sea-bed both under territorial seas and under the high seas. Such is a catalogue of public ownership of petroleum resources in Canada. ${ }^{20}$ The unresolved issues, apart from constitutional changes, are "if" and "when" natural resources will be transferred by Ottawa to the governments of the territories, and what arrangements will be made between Ottawa and the seaward provinces respecting offshore petroleum. On the first issue, opinions clash between federalists who view the northern resources as belonging to all Canadians and provincialists who assert that a basic principle of Canadian federalism is that the people of each region are entitled to exploit the resources of the region for local purposes and benefit."1 On the second issue, former Prime Minister Pearson stated the willingness of the federal govern-

\footnotetext{
18 (1967) 5 Alta. L. Rev. 264.

10 Supra, n. 8.

20 This history is further developed by the writer in Ownership of Natural Resources in the North West Territories, (1967) 5 Alta. L. Rev. 304.

21 See supra., n. 20 where the writer examines the matter further.
} 
ment to negotiate with the provinces, including British Columbia, respecting the offshore minerals notwithstanding the decision of the Supreme Court of Canada favouring the federal government. His successor, Prime Minister Trudeau, is not, to the writer's knowledge, on record with respect to this issue, but it is safe to predict that the last word on the offshore minerals has not yet been said.22

Can it be assumed that the basic arrangement, whereby the provinces rather than the federal government own the mineral resources, will remain intact notwithstanding the winds of constitutional change? Or will ownership of such resources be swept up in the maelstrom of constitutional bargaining? There is ample precedent for ownership by the central government in a federation of all natural resources. The majority of federal systems are so constituted. The ownership of petroleum resources by the federal government of Nigeria has been an underlying cause of the break-away of Biafra. In the United States, it is the federal government that owns mineral resources in the public domain lands.

It is the writer's guess that ownership of the offshore minerals will be a bargaining factor in the impending constitutional changes. But there is no likelihood that the basic premise that the provinces own resources will be challenged. For example, there is simply an assumption that the provinces will continue to own the mineral resources in the model constitution proposed by Messrs. Faribault and Fowler in their book Ten to One. ${ }^{23}$

So far as is known, all other writers about constitutional change make the same assumption. The writer hazards the opinion that, following this basic premise of provincial ownership of resources, the federal government will ultimately transfer northern resources to territorial governments just as it transferred resources to the prairie provinces in the 1930's, but the far north, including the Arctic islands, will likely remain federal preserves.

(b) Revenues from the resources.

A basic conflict between federal and provincial interests in petroleum stems from the fact of provincial ownership of resources. Such ownership gives the province the ability to exact revenues by way of rentals, royalties and bonuses. If similar revenues had to be raised by taxation on production, it is not unlikely that the province would find its tax laws ultra vires as indirect taxation under the present constitution. Further, taxes have to be continually justified to the taxpayer by a demonstration of fiscal need whereas returns based on ownership of the resource are justified at the beginning by the exploitation agreement. The result is that through ownership of petroleum the province has an acceptable and efficient means of raising revenue. The importance of this fact is enhanced when it is realized that the taxing powers of the province under the constitution are in many respects inefficient and unacceptable means of raising revenues. ${ }^{24}$ On the federal side, in

\footnotetext{
22 Since this paper was delivered, federal policy respecting offshore mineral rights has been announced. It includes base lines seaward of the coasts which will mark off federal ownership from provincial ownership, and a 50-50 split of revenues between federal government and the provinces in the federal offshore areas.

23 Ten to One: The Confederation Wager, McLellan and Stewart, Toronto, 1965.

24 W. R. Lederman makes this point in Some Forms and Limitations of Co-operative Federalism, (1967) 45 Can. Bar. Rev. 409, at 411 .
} 
the competition for the oil industry's dollar, there is an historical accumulation of incentive provisions for the mineral extraction industries that substantially reduces the tax burden and leaves the federal treasury the poorer. In result, the federal tax laws permit oil companies to pay higher rentals, royalties and bonuses to the provinces than would otherwise be the case, and a change in these tax laws such as proposed by the Carter Commission on Taxation would result in materially reduced provincial returns.

(c) Control of the business of exploiting the resource.

The purposes for which a province seeks to regulate an industry are not identical with those that motivate the federal government to use its regulating powers, and therefore there are clashes of interests. Quite naturally, a federal government regulates from a national viewpoint, and therefore gives precedence to matters such as national economic planning, fiscal and monetary control, national defence and security, and "good neighbour" relations with other countries. On the other hand, a provincial viewpoint may prefer the local establishment of a petrochemical industry when economic factors dictate that it should be established elsewhere in the country. A provincial government may seek the highest prices for producers of natural gas when the federal government views the public interest as requiring the lowest possible price for consumers. The instances of these clashes of interest need not be multiplied.

It is in this area of the regulation of economic activity that writers have assailed the extensive powers enjoyed by the provinces under the B.N.A. Act, 1867. Bora Laskin observes that he knows "of no federal system in which the constituent units have as extensive a regulatory authority as have the Provinces of Canada and in which the federal commerce power is as truncated as is that of the central government."2s

(d) Control of the uses to which the resource may be put.

The conflicts in this case are similar in nature to those arising with respect to regulation of the business activities of the petroleum industry. The provincial interest may demand immediate and rapid exploitation of a resource by all-comers whereas the federal interest calls for cautious husbandry by Canadian nationals. The provincial government is likely to consider only provincial needs when it grants a licence for export whether to another province or to another country whereas the federal government will look to national needs should it have control over exportation. Federal policies with respect to marketing may take into account matters such as relations with foreign states which would be entirely extraneous to provincial considerations. Again, instances need not be multiplied.

(4) Guidelines for the Industry in the Process of Change.

When specific proposals for constitutional reform are placed before the Canadian people, lawyers will be called on to advise their companies and clients so that they may assess their positions and formulate their reactions to the proposals. Obviously, the guidelines which are

25 Laskin, Reflections on the Canadian Constitution After the First Century, (1967) 45 Can. Bar. Rev. 395, at 400 . 
offered for approaching this task can only be stated in broad generalities at this time.

The most important point to be made is to emphasize the writer's opinion that the philosophical and institutional changes will be equally as significant as, and possibly more significant than, changes in the distribution of legislative powers. Philosophcally, the entrenchement of a Bill of Rights in the Canadian constitution, particularly if it follows the United States model by including due process of law, will have a profound effect on the totality of Canadian jurisprudence. So far as institutional changes are concerned, it has been noted that the pattern of legislative organization for the petroleum industry has been influenced as much by the reluctance of Canadians to challenge the validity of legislation in the courts as it has been by the distribution of legislative powers in the B.N.A. Act, 1867. Therefore, if the institutional changes, and, in particular, the establishment of a new constitutional tribunal, make enforcement of the distribution of legislative powers between the federal and provincial governments a fashionable procedure once again, then the definitions of those powers in the constitution will assume a new significance whether they are changed or not. The Ottawa constitutional advisors are pondering the reasons why Canadians are loathe to litigate the constitution. Maybe they will propose a procedure similar to the certiorari procedure of the United States so that constitutional issues can proceed expeditiously and inexpensively directly to the constitutional tribunal. In any event, it does not take much imagination to be aware that if the challenge of legislation on constitutional grounds should suddenly become popular under today's conditions, there would be a turbulent time for the oil industry though nothing else should change.

The prediction that the pattern of public ownership of mineral resources will continue largely unchanged in any new constitution means that, no matter how legislative powers are redistributed between governments, there will remain a major role for the provinces to play in the exploitation of the petroleum resources. The proprietary powers are bound to be significant. The writer has suggested on other occasions that the proprietary powers of the provincial governments may make up for the deficiencies in legislative powers should the provinces be called on to defend their right to licence the export of gas or to ration the production of oil. ${ }^{20}$

In other respects, ownership of the resource will be significant. Federal ownership of oil in the Yukon or North West Territories, should it be discovered in large quantities, could induce federal parliamentarians to flex their legislative muscles to ensure that this far-off oil is carried through pipelines at prices and under conditions that will ensure entry to the limited North American markets for crude. The contest over ownership of the offshore petroleum resources could lead to interesting administrative arrangements if the federal government continues to recognize, as former Prime Minister Pearson seemed to do, that the seaward provinces have interests in this petroleum to be acknowledged by some form of joint regulation and administration, and

20 G. A. Holland comments on this matter in The Federal Case, (1964) 3 Alta. L. Rev. 393 , at 407 
some sharing of revenues. ${ }^{27}$ The Australians have recently promulgated a Common Code for offshore petroleum under an agreement between the Commonwealth and the states. This agreement provides for a common administration of the code under a state authority, a sharing of revenues between the Commonwealth and the littoral state, and the entrenchment of the code so that neither side can unilaterally change the rules of the game. If, to the constitutional expert, this arrangement seems like unconstitutional delegation of legislative competence from the Commonwealth to the state and vice versa, it would be-even under the Australian constitution-were it not for an extraordinary provision at the conclusion of the agreement which reads:

26. The Governments acknowledge that this Agreement is not intended to create legal relationships judiciable in a Court of Law but declare that the Agreement shall be construed and given effect to by the parties in all respects according to the true meaning and spirit thereof.28

Possibly, in these arrangements there are lessons for future Canadian developments in the offshore areas. ${ }^{20}$

Finally the legislative power to regulate economic activity so far as it relates to the petroleum industry should be dealt with. It is in this area that constitutional writers say that the federal government has been "short-changed" by the courts. Certainly, any comparative study of the "commerce" clause in the United States constitution and of the "trade and commerce" clause in the Canadian constitution ${ }^{30}$ reveals that judicial interpretation, while expanding the content of the former, has, in Bora Laskin's words, truncated the force of the latter. Even so, this paper has shown that, truncated as it may be, the federal power can probably overturn much of the provincial legislation which now provides the regulatory framework for the Canadian oil industry. The options therefore appear to be threefold. For the provincialist, he may seek amendment of ss. 91 and 92 of the B.N.A. Act, 1867 to give legal sanction to the regulatory system as it now prevails. In this case, the provinces would clearly play the dominant role in the regulation of the petroleum industry. For the federalist, even a change in the constitutional court without any re-definition of the "trade and commerce" power might accomplish the increased federal jurisdiction that he advocates, but a surer pathway to federal power would be a re-statement of the "trade and commerce" clause to place the regulation of national economic activity clearly within the competence of Parliament.

The third option is neither for the provincialist nor for the federalist, but for him who believes that any form of power is better in a free society for being offset by a countervailing power. In his view, the "saw-off" which now prevails between federal and provincial governments, whereby the provincial government proceeds from ownership of the resource to a regulatory system for the industry, but does not press too far because of doubtful legislative competence, and the federal

it See n, 22, ante.

$\because$ The agreement, dated October 16, 1967, is entitled "Agreement Relating to the Exploration for, and the Exploitation of, the Petroleum Resources, and Certain Other Resources, of the Continental Shelf of Australia and of Certain Territories of the Commonwealth and of Certain Other Submerged Lands."

20 For the writer's analysis of this Australian legislation, see Australia's Off-shore Petroleum Common Code, (1968) 3 U.B.C. L. Rev. 1.

30 The definitive study is Alexander Smith. The Commerce Power in Canada and the United States, Butterworths, Toronto, 1963. 
government co-operates with this provincial regulation, confident that it has the legislative authority to curb excesses, is not a case of mutual emasculation of legislative competencies, but a healthy balance of power. One who is skeptical of this view may well ask himself whether he believes the oil industry would have fared better than the National Parks' residents had total legislative power over the industry been vested in the hands of the Minister of Indian Affairs and Northern Development during the past few years-or whether the industry would have prospered so well under the exclusive ministrations of the provincial regimes.

It is not for the writer to choose among these options. It is clear that there is much at stake in the forthcoming constitutional conferences, and that for the oil industry, as well as for other industries, there must be a careful definition of interests and a clear statement of objectives. 